\title{
洗浄性を考慮した複合砥粒の開発と谷研磨特性*
}

\author{
一廼穂 直聡*1, 山口雄 也*2, 櫻 井健 行*2 $^{* 2}$ \\ 谷 泰 弘 $^{* 3}$, 金 泰 元 $^{* 3}$

\section{Development of Composite Abrasives Considering Cleanability of Workpieces and Their Polishing Characteristics}

\author{
Naoaki ICHINOHO*4, Yuya YAMAGUCHI, Takeyuki SAKURAI, \\ Yasuhiro TANI and Taewon KIM \\ ${ }^{* 4}$ College of Science and Engineering, Ritsumeikan University, \\ 1-1-1 Noji, Higashi, Kusatsu-shi, Shiga, 525-8577 Japan
}

\begin{abstract}
The specific gravity of cerium oxide used for glass polishing as abrasives is very heavy so that the cleanability of workpieces and the dispersibility in polishing slurry are very bad. Then composite abrasives that put the abrasive grains on the surface of the polymer particles with light specific gravity were developed in this paper. For manufacturing the composite abrasives, it was found that the hybrid mixer with two axis rotation method was more suitable than hybridization system with one axis rotation method. The residual abrasives were still observed though cleanability was considerably improved by using the composite abrasives. Because it was made clear that the loose abrasives were deteriorated of the cleanability, classification using the subsidence speed difference was carried out. As the result cleanability and surface finish were improved very much using the classified composite abrasives. Next the material of the mother particle was examined. The polyurethane was suitable for glass polishing, and higher removal rate was obtained than that of conventional polishing.
\end{abstract}

Key Words : Abrasive Grain, Slurry, Polishing, Glass, Cerium Oxide, Polymer, Cleaning, Hybrid Mixer

\section{1. 粕 曹}

ガラス研磨においては従来から酸化セリウムが砥粒とし て加工に用いられており，酸化泣よりも高精度, 高 能率を達成し, かつ安価に手に入る代替碈粒は現在のとこ ろ存在しない，一方, 酸化セリウム碈粒は比重が 6.8〜 $7.3 \mathrm{~g} / \mathrm{cm}^{3}$ と大きいため沈澱速度が速く, 分散性力゙覀いこと が短所として挙げられる. また，一度沈澱してしまうと再 分散ぶ容易でないといった問題点もある.このため, 適当 な分散剂が併用されている(1)、(2)が，この使用が研磨能率を 低下させる原因となっている. 一方, 著者らが開発した複 合粒子研磨法 ${ }^{(3) \text { (4) }}$ では，比重が $1 \sim 1.5 \mathrm{~g} / \mathrm{cm}^{3}$ のポリマ微粒 子を母粒子として使用し，これに砥粒を電気的に付着させ て研磨を行うため, 分散性を大幅に向上させることが可能 になった．またこの研磨法では砥棜拊着したポリマ微 粒子がミクロな研磨パッドとして作用し，これが動き回る

\footnotetext{
* 原稿受付 2009 年 3 月 23 日

*1 学生員, 立命館大学理工学部 (-525-8577 草津市野路東 11-1).

*2 立命館大学理工学部.

*3 正員, 立命館大学理工学部.

E-mail : rm001050@ed.ritsumei.ac.jp
}

ために縁ダレがなく形状精度の高い加工が行える.しかし， 複合粒子研磨法では，砥粒力゙遊離して存在するために，研 磨機械や工作物一の遊離した砥粒の付着が激しく，加工後 の工作物の洗净性㴗いといった課題力残されていた この問題を解決するために，著者らは複合粒子研磨法に おけるポリマ微粒子の表面に砥粒が付着した粒子（以下複 合砥粒と称する）に着目した。 つまり，本研究では母粒子 に比重の軽いポリマ微柆子を用い，乾式の状態て機材的手 法を用いて子粒子として碈粒を母粒子表面に被覆させるこ とで, 複合砥粒を倉成した。研磨特性や工作物の洗浄性を 考虑しながら，複合砥粓の製造力法や母粒子の材質につい て検即を行ったので, 報告する.

\section{2. 被合的整作方法}

ます複合砥粒を作製するために，図 1 に示されるハイブ

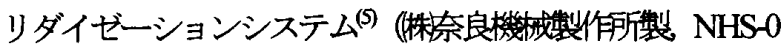
型を使用した。これは機树的作用により乾式て微枌体の 表面を改質し，機能性複合個体を作製する装置である. こ のプロセスの原理としては，母粒子となるポリマ微粒子と 子粒子である砥粒を混合分散させ，これらを装置本体に投 


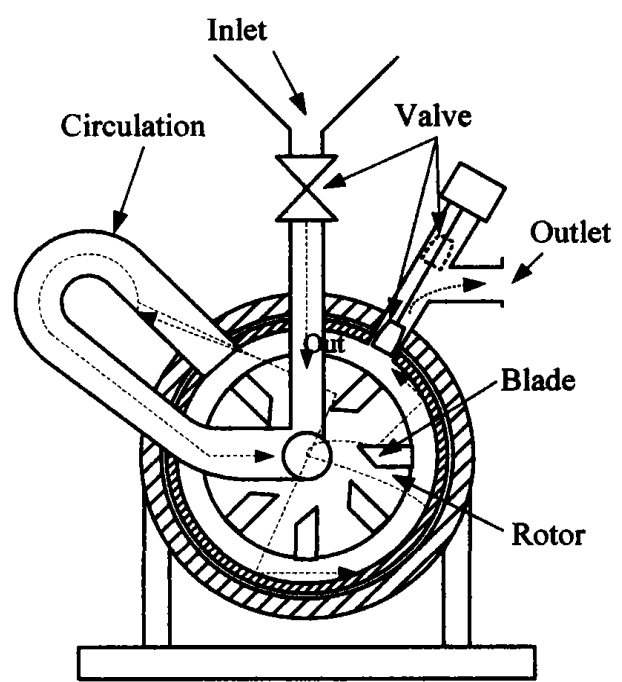

Fig. 1 Hybridization system

Table 1 Constituent material of composite abrasives

\begin{tabular}{|c|c|c|}
\hline Part & Material & Mean diameter \\
\hline $\begin{array}{c}\text { Mother } \\
\text { particle }\end{array}$ & Polystyrene (PS) & $6.3 \mu \mathrm{m}$ \\
\hline $\begin{array}{c}\text { Child } \\
\text { particle }\end{array}$ & $\begin{array}{c}\text { Cerium oxide } \\
\left(\mathrm{CeO}_{2}\right)\end{array}$ & $1.2 \mu \mathrm{m}$ \\
\hline
\end{tabular}

入し，機内に分散させながら，㣫掏力を主体に粒子の相互 作用も含め, 压縮，摩察，剪断力等の機械的作用を繰り返 し与え，粒子間の固定化，成膜化，粒形化の処理を均一に 行うものである. ポリマ微粒子と碈粒の複合化に用いた母 粒子と子粒子の材質と粒径を, 表 1 に示す．まずポリスチ レン粒子 (積水化成品工業株 SBX-6, 以下PS 粒子と記述 する）と酸化セリウ入砥粒（昭和電工株製A-10）を体積比 で1：1の割合で混合し，図 2(a)にボれるような複合砥 粒を製作した。

この複合砥粒を用いて，表 2 に示す条件でソーダガラス

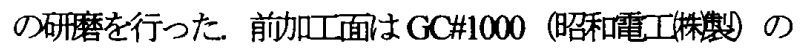
碈粒を用いて錆鉄定盤でラッピングして得られたものであ る. 研磿能率 P は研磨前後の工作物の重量差を電子天秤に て測定し，工作物の比重力的平均的な除去速度を算出した 仕上け面粗さは白色光干涉式非接触 3 次元表面形状・粗さ 測定機（ZygoNewView5032，以下Zygo と表記する）を用 いて測定し，断面曲線より算術平均高さを求女粗さ $\mathrm{Pa}$ の評 価を行った。

実験の結果，図 3 に示されるように同一条件下での酸化 セリウム砥粒を用いて行った通常研磨の5割強の研磨能率 しか得ることができなかかたここれは図 2(a)に示されるよ うに母粒子の表面 の砥粒の付着が少なからたためと思わ れた，そこで，母粒子と子粒子の混合割合を $1: 1.5,1: 2$ と変化させて複合碈粒を製作したが，図2(b)およひ(c)に示

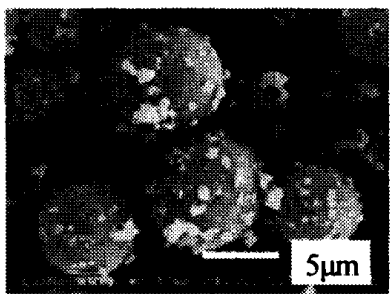

(a) PS : $\mathrm{CaO}_{2}=1: 1$

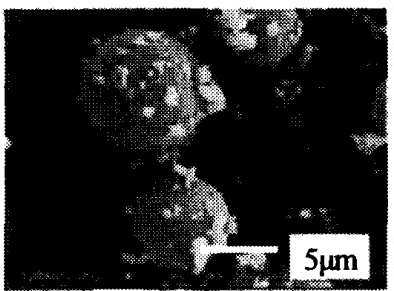

(c) PS: $\mathrm{CaO}_{2}=1: 2$

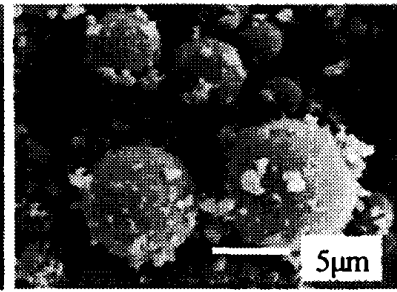

(b) $\mathrm{PS}: \mathrm{CoO}_{2}=1: 1.5$

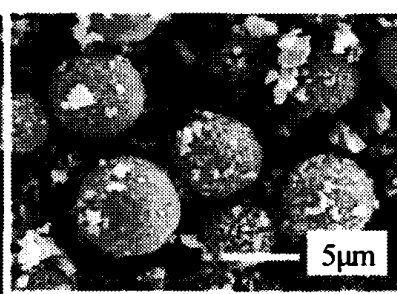

(d) $\mathrm{Ny}: \mathrm{COO}_{2}=1: 2$
Fig 2 Composite abrasives made by using hybridization system

Table 2 Polishing condition

\begin{tabular}{|l|l|}
\hline Machine & $\begin{array}{l}\text { Lapping machine SPL-15 } \\
\text { Okamoto machine tool works ,Ltd. }\end{array}$ \\
\hline Workpiece & $\begin{array}{l}\phi 20 \times 110 \mathrm{~mm} \text { Soda glass } \\
\text { with } 02 \mu \mathrm{m} \text { Ra surface finishing }\end{array}$ \\
\hline Pressure & $20 \mathrm{kPa}$ \\
\hline Work rotation & $60 \mathrm{~mm}$ \\
\hline Lap rotation & $60 \mathrm{pm}$ \\
\hline Polishing time & $30 \mathrm{~min}$ \\
\hline $\begin{array}{l}\text { Concentration of } \\
\text { Composite abrasives }\end{array}$ & $3.0 \mathrm{wt} \%$ \\
\hline Supply rate of slurry & $25 \mathrm{~mL} / \mathrm{min}$ \\
\hline Polishing pad & $\begin{array}{l}\text { Cerium pad KSP-66A } \\
\text { Kokonoe electric Co,Ltd. }\end{array}$ \\
\hline
\end{tabular}

DRemoval rate $\quad$ Surface roughness

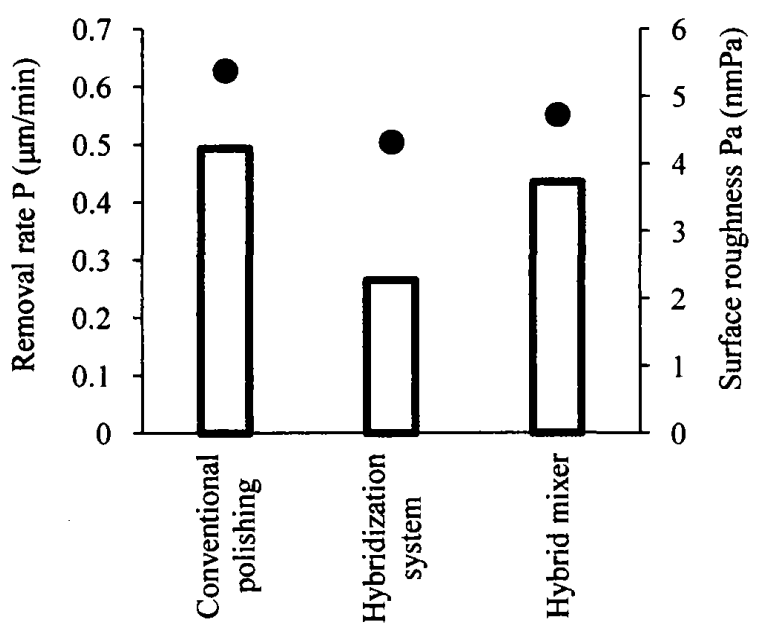

Fig. 3 Polishing characteristics by manufacturing method 


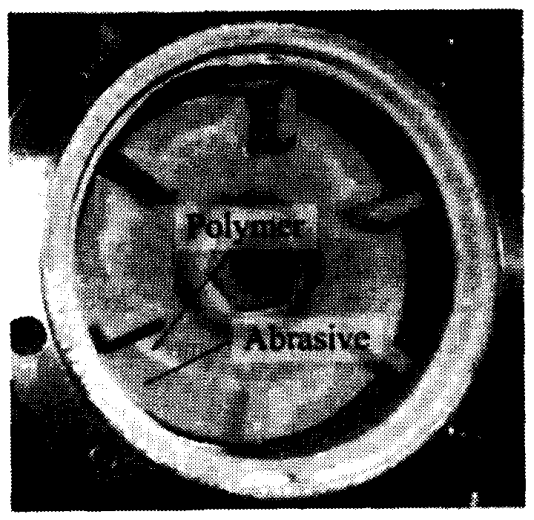

Fig 4 Adhesion in drum of hybridization system

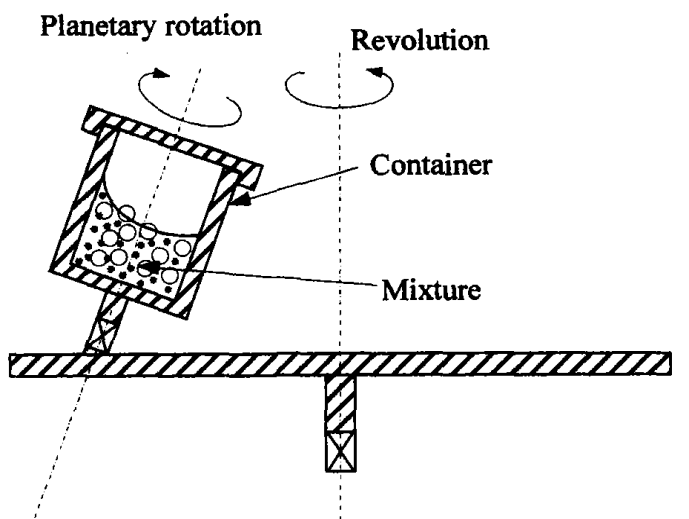

Fig. 5 Mixing mechanism of a hybrid mixer

されるように砥粒の付着はあまり改善されず，これらの複 合砥粒を用いて行った研磨においても研磨能率の向上はは とんと確認できなかかた，そこで，PS粒子よりも軟らかい ナイロン粒子を用いて体積比 $1: 2$ で複合碈粒を図2(d)のよ うに作製し，同様こ研磨夹験を行ったが，や性り研磨能率 は改善されなからた

そこで，このように砥粒の付着が十分でなかかた理由は， ハイブリダイゼーションシステムの作用メカニズムにある と考光た，図 4 は複合秪粒を製作した際のハイブリダイゼ ーションシステムのドラムの中の写真である. 比重の重、 酸化セリウム碈粒はドラムの外周に付着しており，比重の 軽いポリマ微粒子はそれよりも内側に付着しており，これ らが分離していることが分かる. Mブリダイゼーション システムのように1軸の回転のみによる混合では，母粒子 と子粒子の比重差により分離が生じ，付着が十分に行えな いと判断された.

そこで，この問題を解决すべく，図 5 のような公転とと もに自転云行える2軸の回軾機構を持ったハイブリッドミ キサ（懒キ一エンス製 HM-500）の採用を試みた。予備実 験の結果では，PS粒子に対する酸化セリウム砥粒の重量が 12倍以下の条件では母粒子に対する砥粒の付着が十分では

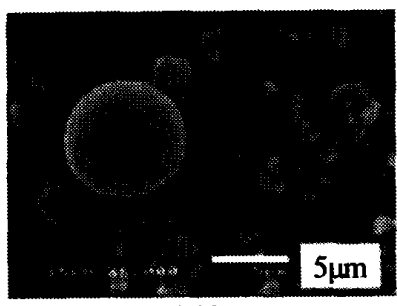

(a) $30 \mathrm{~s}$

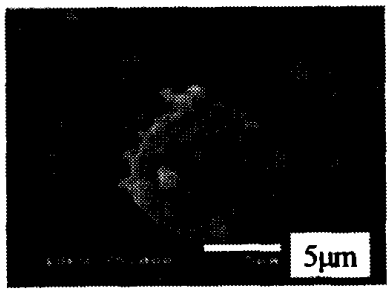

(c) $120 \mathrm{~s}$

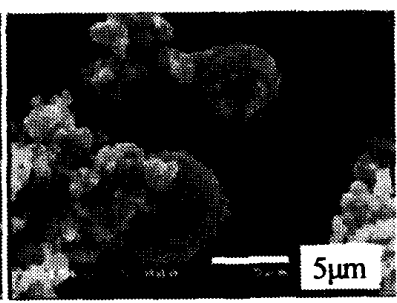

(b) $60 \mathrm{~s}$

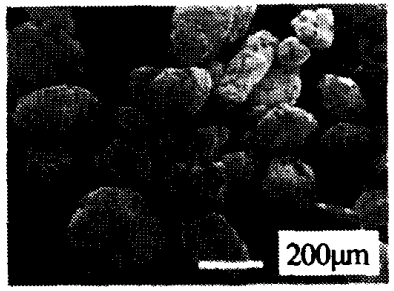

(d) $180 \mathrm{~s}$
Fig. 6 Effect of mixing time on adhesion of abrasives

なく，それ以上の混合比においては混合時間とともに付着 量が増吋する傾向にあった。 そこで，母粒子と子粒子の重 量比は1:12 に固定した 図6に回軾数を公転速度 $2000 \mathrm{~mm}$ ， 自転速度 800mpm で一定とし，混合時間を $30 \mathrm{~s}, 60 \mathrm{~s} ， 120 \mathrm{~s}$, 180 s と増加させた際こ得られた複合秪粒を示す. 30 秒間混 合を行ったものでは付着はかずかしかなく,120秒間混合を 行うと，ポリマ微粒子表面を砥粒力覆鿵すほどに付着し ていることが見てわかる.また，150秒以上の混合時間では， 図 6(d)に示すように砥粒とポリマ微粒子の凝集塊が生じ， 研磨に用いることは不可能となった。

ハイブリッドミキサにて作製した複合砥粒の研碧特性を 評価するために，表 2 に示す研磨条件でソーダガラスの平 面研磨を行った. その結果，ハブリッドミキサで作製し

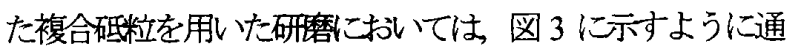
常研磨に近、研磨能率力゙得られ，砥粒の母粒子付着の 改善力研磨能率に大きく影響することが半归した。こよ らにメブリッドミキサにより製作した複合砥粒を用いた 場合，研磨能率は若十低くなっているが，仕上げ面粗さは その割合以上に良くなっており，このことは加圧等の研 磨条件を変化させることで同等の研磨特性が得られること を示している.

\section{3. 分釉に上る洗浄性の向上}

前述のように複合砥粒を用いると工作物の洗浄性が向上 するものと期待されていた そこで, 複合砥粒を用いた研 磨における洗浄性を実際乙確認寸るため，表2の条件て研 磨した工作物を超音波洗浄器で 1 分間の洗浄を行った後, 加工面の観察を行った，その結果，図7(b)に二示されるよう に通常研磨（図7(a)）とほとんど変わらない碈粒の付着状 態力観察された，ただ，複合砥粒を用いた場合では，凝集 碈粒の付着は少ないように思わ机た。こ机は母粒子にもと 


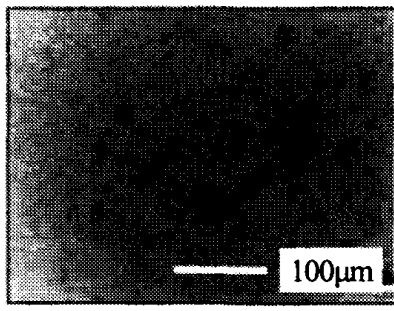

(a)Convertional polishing

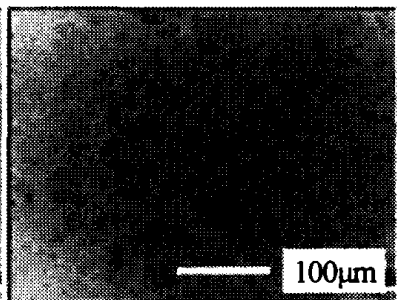

(b) Polishing using compositeabrasive withoutchssification

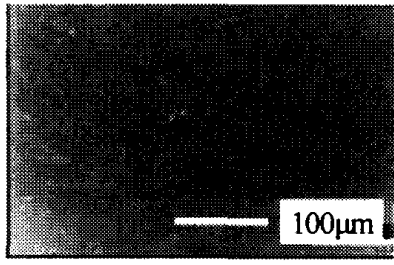

(c)Polishingusingcompositeabra after lstclassification

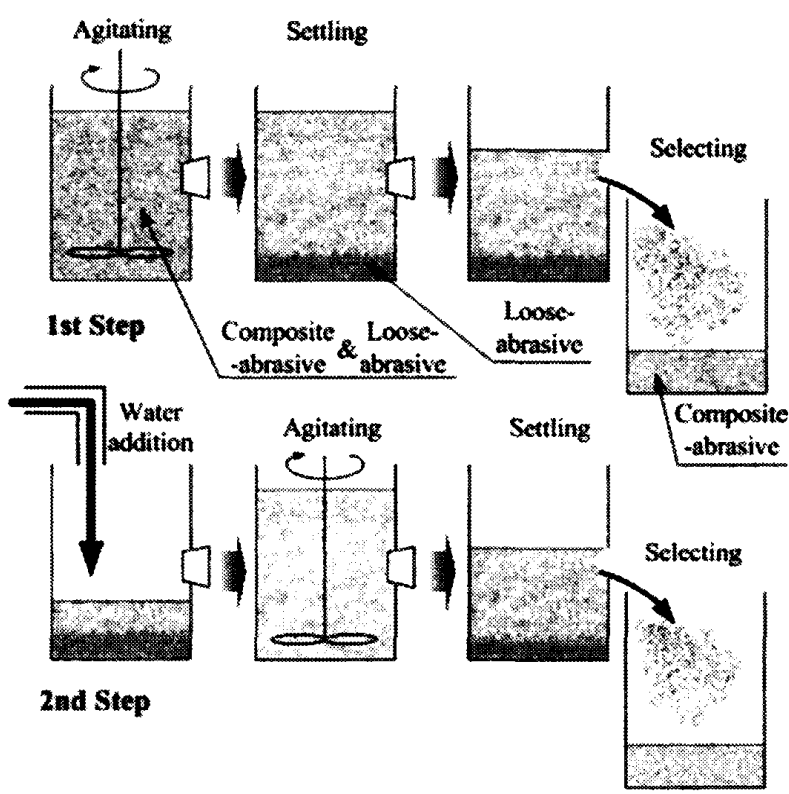

Fig. 8 Classification process

もと付着していた界面活性阂の作用によるものと考えられ る. また，洗浄性が向上しなかった理由についは，ポリ マ母粒子に付着していない遊離した砥粒によるものと 考えられる.

そこで，より高い洗浄性を実現するために，遊離し た酸化セリウム砥粒と複合碈粒を分離することにした。 こうした分級方法としては, 遠心分離, 浮遊分離, ふ るい分け分級など種々の方法があるが，この場合作成 した複合砥粒の比重が約 $2.2 \mathrm{~g} / \mathrm{cm}^{3}$ であるのに対して, 使用した酸化セリウムの比重は約 $6.9 \mathrm{~g} / \mathrm{cm}^{3}$ で, 摜拌後 の沈殿時間が複合砥粒で約 35 秒であったのに対して， 酸化セリウム砥粒の沈殿時間は約 20 秒と大きく異な

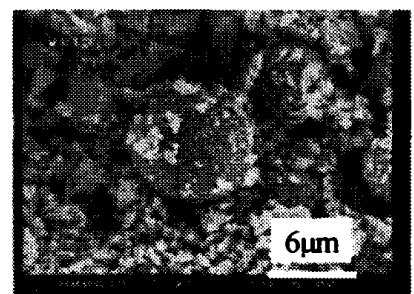

(a) Before classification

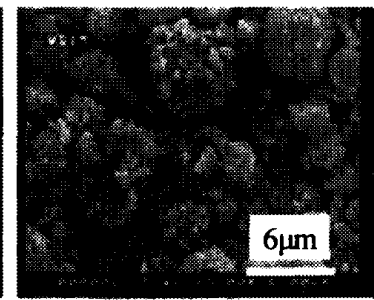

(b) After classification
Fig.9 Classification effect for composite abrasives

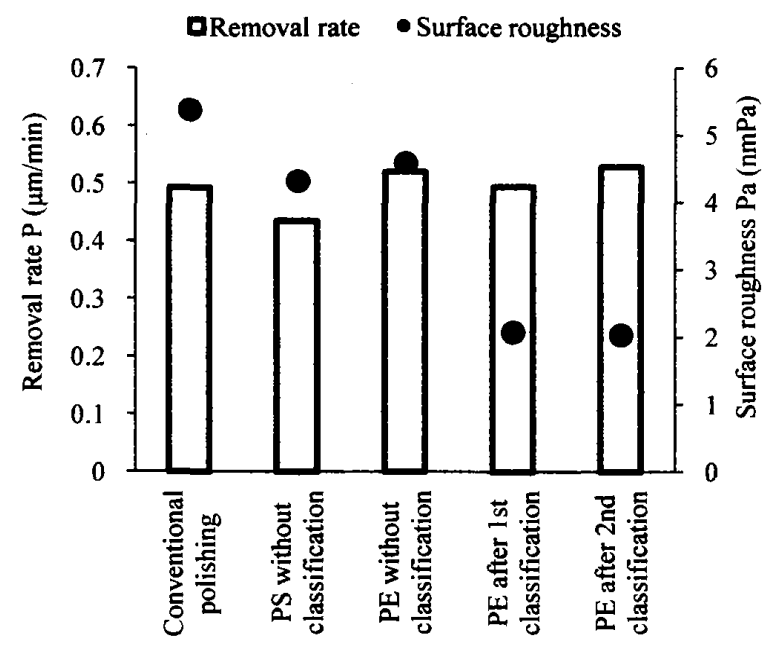

Fig. 10 Effect of shurry classification on polishing characteristics

っていたことから，沈降速度差を利用した分級を行うこと とした. 手順としては，ます製作した複合砥粒を純水と混 合し， 20 分間掜汼する. その後 25 秒間静置した後に 図8 に示される容器の側面に設けた栓を開き, 栓よりも上部に ある混合液を取り出したこうして得たものを1 段階分級 後の複合砥粒とし，この操作を抽出した混合液に対して再 度行って得たものを 2 段階分級後の複合碈粒とした．分級 前後の複合碴粒のSEM 写真を図9に示す. 分級を行うこと により母粒子周刀の遊離した砥粒が大幅に減少しているこ とがわかる.このようにして分級を 1 回および2回施した 複合砥粒を用いて，表 2 の研磨条件でソーダガラスの研磨 夷験を行った. その加面を観察した結果，図7(c)および(d) に示すように表面の洗浄性が顕著に向上されていることが 確認できた。特に 2 段階分級を施した複合秪粒を用いて研 磨した加工面には，ほとんと砥粒の残留は見られなかった。

複合粒子研磨法では坎質の母粒子を用いた方が，研磨能 率が向上することが归明しているため(4), 複合碴粒による研 磨こおいてもPS 粒子よりも軟質の母粒子を用いた方が, 研 磨能率が向上すると思われた。 そこで，住友精化林製のポ リエチレン粒子EA-209（以下PE粒子と称する）の適用を 検討したその結果，図10に示すようにPE粒子を用いた 


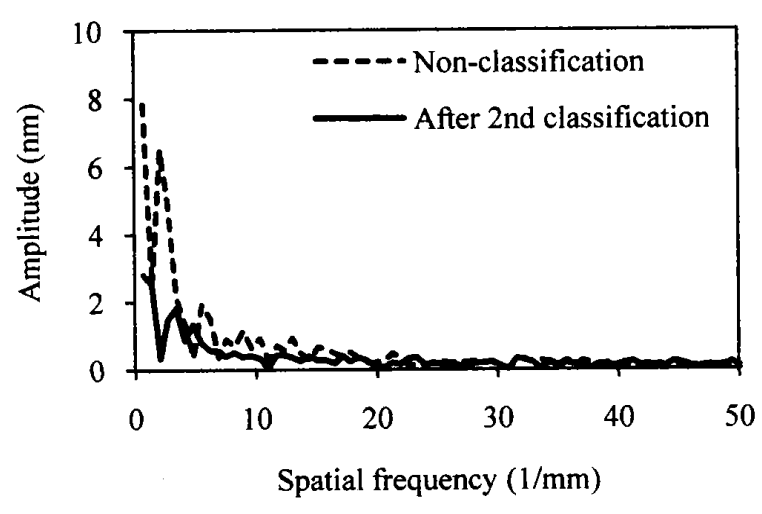

Fig 11 Effect of classification in spatial frequency

Table 3 Polymer material for composite abrasives

\begin{tabular}{|c|c|c|c|c|}
\hline Material & $\begin{array}{c}\text { Abbreviated } \\
\text { name }\end{array}$ & $\begin{array}{c}\text { Model } \\
\text { name }\end{array}$ & $\begin{array}{c}\text { Mean } \\
\text { diameter } \\
(\mu \mathrm{m})\end{array}$ & $\begin{array}{c}10 \% \\
\text { Compreasive } \\
\text { strength(MPa) }\end{array}$ \\
\hline Polystyrene & PS & SBX-6 & 6.3 & 21.9 \\
\hline Polyethylene & PE & EA-209 & 93 & 3.28 \\
\hline \multirow{3}{*}{ Polyurethane } & UH & U-600 & 103 & 13.6 \\
\cline { 2 - 5 } & UM & CF-600T & 102 & 0.63 \\
\cline { 2 - 5 } & US & C600 & 10.2 & 0.42 \\
\hline
\end{tabular}

複合柢粒による研磨つ研磨能率はPS 粒子よりも向上し, 通 常研磨と同等であった。仕上げ面粗さは，通常研磨よりも 優れたものとなった. 次にこの研磨能率の高いPE粒子を 用いた複合碈粒に分級を施し，研磨特性の評価を行った結 果，同図に示すように研磨能率はほほ同等で，仕上げ面粗 さはほぼ半分に改善されることが半明した，その理由を調 查するために，空間周波数分布をZygoにより求めた，その 結果，図11に示されるように，分級を行うことで低周波数 領域の仕上げ面粗さが大幅に改善されていることが分かか た. 改善の原因として考えられるのは，遊離した砥粒によ り生じる立体障跤効果の減少である.つまり，遊離した砥 粒の低减にともなう複合砥粒の流動性の向上が，一八砥 粒力゙連続して加工する切消距離の短縮に働き，仕上げ面粗 さか㳊善されたものと考えられる。

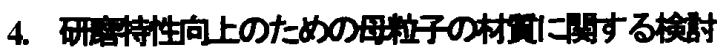

図10によれば，複合碈粒の母粒子としてPS粒子よりも 軟質のPE粒子のほうが優れていることが分かる.このよう に母粒子の材質は研磨特性に大きく影響方る。研磨の現場 においては仕上げ面粗さよりも研磨能率方優先されるため, 研磨能率のさらなる向上を目指して母粒子の材質に関して 検扵を行うこととした，検据には表3のように新たに粒径 およひ硬度の異なる 3 種顛のポリウレタン粒子を用いた。 10\%圧箱宿能度に見られるように使用したポリウレタン粒子 は，高、研磨能率を示したPE粒子とPS 粒子の閒にあるも のと, PE粒子よりもさらに軟質のものを検討の対象とした

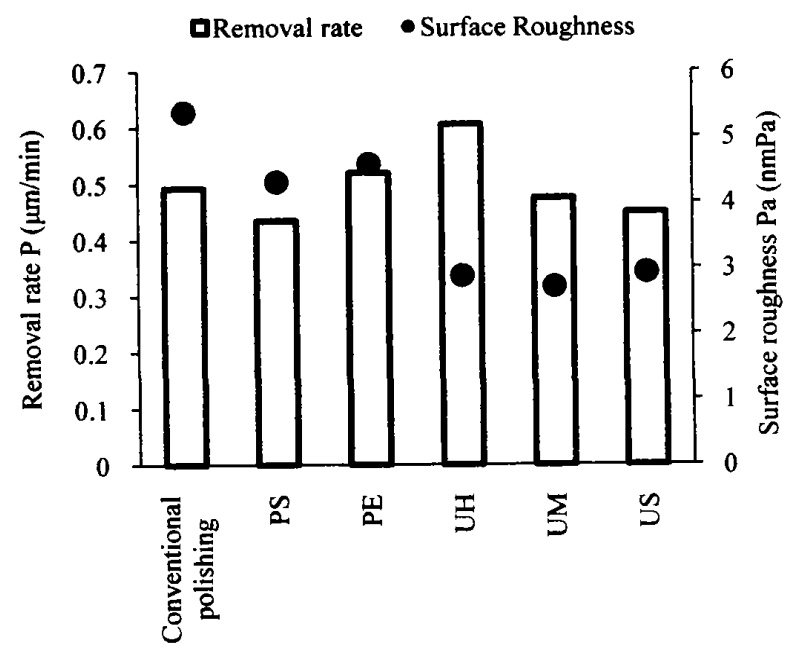

Fig. 12 Polishing characteristics using by various composited abrasives

ウレタン微粒子としては根上工業制のアートパール U-600T, CF-600T, C600の3種類を使用した. それぞれ U-600T をUH粒子(Hard), CF-600T をUM 粒子(Medium), $\mathrm{C} 600$ 透明をUS 粒子(Soft)と呼称する. これらのポリマ微粒 子を用いて製作した複合碈粒を研磨加几適用した。この とき，複合砥粒の製作には第2章のハイブリッドミキサを 用いた。母粒子によって碈粒の付着状態は若千異なり，混 合時間にともない 研磨能率は向上する傾向にあったが， 120s 以上では全ての母粒子に対して研磨能率の変化がほと んど見られなかった. したがって，すべての母粒子に対し て混合時間は 120 s て固定して複合碈粒を製作した。

表2 の実験条件で研磨を行った結果を, 図 12 に示す.UH 粒子を用いると PE 粒子を用いた時以上に研磨能率が向上 し，また仕上げ面粗さも改善された。研磨能率の向上の原 因としては，PE粒子やUH粒子の方が，PS粒子よりも軟 らかく，粒径が大きいため研磨时に発生する熱か澓合碈粒 に蓄積され，化学的研磨作用が活性化したためであると考 えられる. 一方，UH粒子よりも軟質であるUM粒子，US 粒子を用いた複合碈粒て怢上け面粗さは優れるものの， 研磨能率は低下寸る結果となった。これは母粒子があまり に軟らか寸ぎたために研磨パッドに埋め込まれてしまい， 複合碈粒としてあまり作用できなからたためと考えられる.

各々のポリマ粒子の $10 \%$ 圧縮能度之研磨能率との関係を 図13に示す.このように一定の範用では圧樎強度と研磨能 率は正の相関を現わし，約 $15 \mathrm{MPa}$ の圧維強度で最大の研磨 能率を示し，その後低下していることがわかる．つまり， ポリマ粒子の硬さが一定以上を越えると, 研磨能率には逆 効果があることになる.

また，図14に各々の研磨後の工作物の縁形犾を示す。測 定にはZygo を使用し，外周から $1.5 \mathrm{~mm}$ の範井内で形状の 測定を行った. PS 粒子やPE粒子を母粒子とした複合砥粒 
を用いた研磨の場合には通常研磨より縁での曲率半径が小 さくなったが，UH粒子を母粒子とした複合秪粒では縁で の曲率半径泣逆に大きくなった これは，母粒子の材質が 研磨パッドと同じウレタン樹脂を用いた場合の特異的な傾 向であり, 研磨パッドと母粒子との間で粘着力が生じ, 複 合砥粒力慟きにくくなったためと思われる.

\section{5. 結 言}

機城的作用によりポリマ粒子の表面に酸化セリウム碈粒 を付着させ，複合砥粒を作製し，それをガラス研磨に適用 した結果，以下のような結論を得た

1) 2 軸の回転機構を持つハブリッドミキサを用いてポリ マ微粒子と酸化セリウ入砥粓の複合化を行うことで，母 粒子の表面を覆 鿵すのに十分な量の酸化セリウム砥粒 が付着できることを確認した。

2) 沈降速度差を利用した沈降分級を適用した結果，酸化セ リウム砥粒のみを用いた研磨法と同等の研磨能率が得ら れた上，優れた仕上げ面粗さと大幅な洗浄性の向上が可 能になった，仕上げ面粗さに対する効果では長波長の成 分で顕著であることが判明した。

3）複合砥粒の母粒子として種々の材質の微粒子に関して検 討を行った結果，ポリマ微粒子の $10 \%$ 圧縮能度に関して 研磨能率に極大値を有することが判明した。

\section{辞}

本研究にあたりポリマ微粒子の提供を頂きました積水化

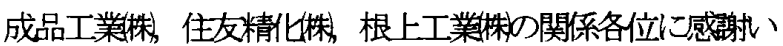
たします

\section{文献}

(1) Yasuhiro YAYAMA and Takesuke YAMAGUCHI, Japanese patent publication, 2001-294848 (2001.10.03).

(2) Tomoyuki MASUDA and Nobuhiko OHARA, Japanese patent publication, 2000-144112(2000.0526).

(3) Yishen LU, Yasuhiro TANI and Kenji KAWATA, Proposal of Mirmor Finishing Technology without Using a Polishing Pad(Development of 4Body Finishing Technology Using Particles), Transactions of the Japan Society of Mechanical Engineers, Series C, Vol. 68, №.674 (2002), pp. 262-267.

(4) Sanaki HORIMOTO, Kenji KAWATA, Toshiyuki ENOMOTO and Yasuhiro TANI, The role of carrier particles in an advanced four body finishing utilizing polymer particles, Journal of the Japan Society of Grinding Engineers, Vol. 47, No.6 (2003), pp. 320-325

(5) Takashi ISHIZAKA and Yuji KIKUCHI, Jopamese patent publication, H06-107714 (1994.04.19).

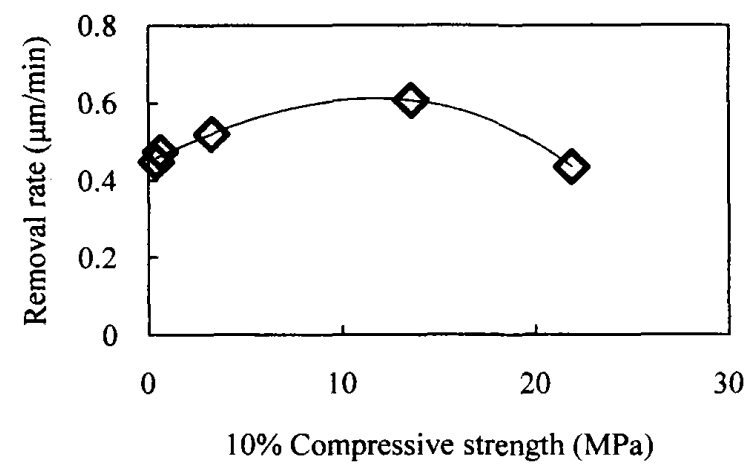

Fig. 13 Relationship between compressive strength and removal rate

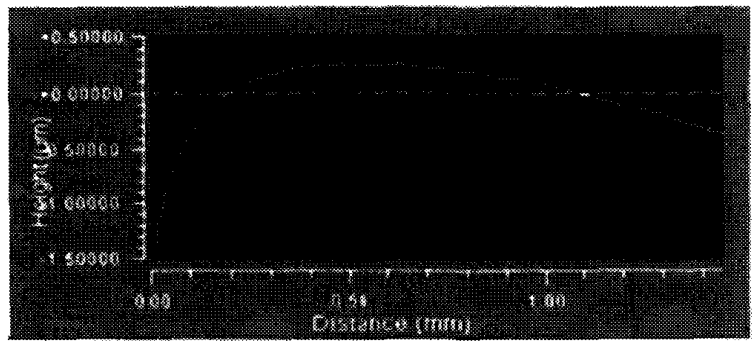

(a) Case of Conventional polishing

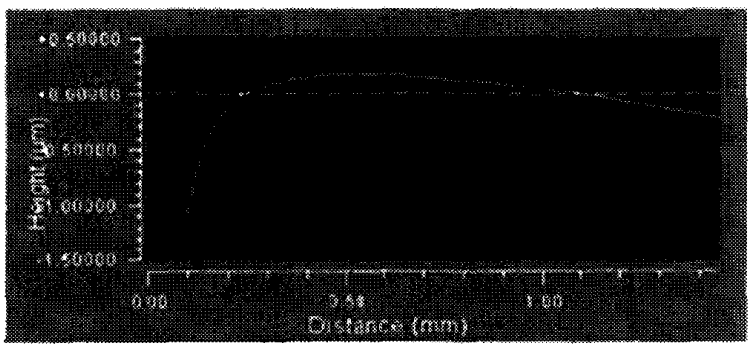

(b) Case of Polystyrene composite abrasive

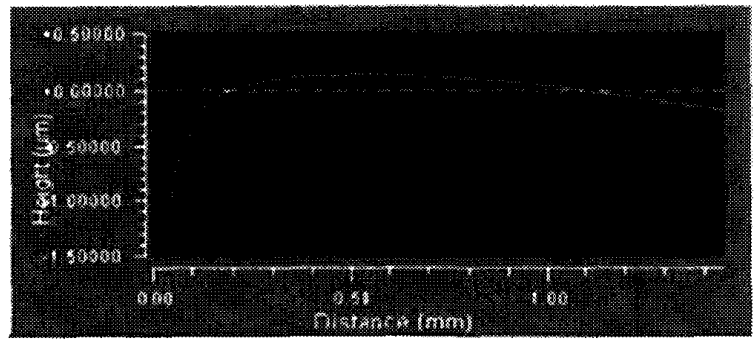

(c) Case of Polyethylene composite abrasive

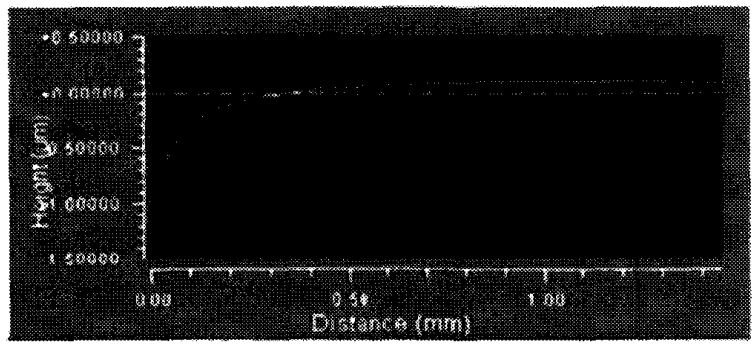

(d) Case of Polyurethane composite abrasive

Fig. 14 Improvement of edge geometry using by composite abrasives 